\title{
LEARNER ERRORS IN WRITING DESCRIPTIVE TEXT MADE BY STUDENTS OF SMP AL ISLAM KARTASURA
}

\author{
Dinar Rizqi Amalia \\ Alumni Universitas Muhammadiyah of Surakarta \\ dinzamalia@gmail.com \\ Phone 085741368091
}

\begin{abstract}
The study aims at describing the learners 'error made by eighth grade students of SMP AL Islam Kartasura in their writing descriptive text; identifying the types of lexical error, syntactical errors, and discourse errors; explaining the frequency of each type of errors; describing the dominant type of errors; and identifying the sources of error. The type of this research is descriptive qualitative research. In collecting the data, the writer uses elicitation and documentation technique. There are some steps of collecting the data; asking the students to write descriptive text, collecting the data in form of erroneous sentences and paragraph, identifying the composition, marking the types of error, and at last, listing the erroneous sentences and classifying them into the classification of errors. The collected data are analyzed using Dulay, Burt and Krashen classification of errors theory, frequency of each type of error using Slamet's theory, and Brown's theory for sources of error. The results of the research show that the eighth grade students of SMP AL Islam Kartasura make 291 errors in their composition which are classified into three categories of error based on the combination of linguistic category and surface strategy taxonomy. There are lexical errors that cover: misspelling 12,37\% and literal translation (the use of Indonesian construction) 6,87\%. Syntactical error consist of omission of $\{-s\}$ as plural marker $4,12 \%$, omission of $\{-s\}$ as third singular person marker $10,31 \%$, misselection of have instead of has $8,25 \%$, the use of verb-ing in structure phrase 1,72\%, omission of verb 2,40\%, omission of be 1,5\%, addition of be 2,40\%, the use of preposition in prepositional phrase 3,44\%, omission of article 1,37\%, addition of the article $1,72 \%$, misordering in noun phrase 19,93\%, misordering in phrase $1,37 \%$, and the last is addition of unnecessary word 5,50\%. Discourse errors is 2,06\% that cover component of discourse in reference 2,06\%. The writer also finds 2 dominant sources of errors, namely interlingual transfer and intralingual transfer.
\end{abstract}

Keywords: error analysis, descriptive text, linguistic category, surface strategy taxonomy.

\begin{abstract}
ABSTRAK
Studi ini bertujuan untuk menjelaskan kesilapan pelajar oleh siswa SMP AL Islam Kartasura dalam penulisan teks deskriptif; mengidentifitikasi kesalahan leksikal, syntaksis, dan wacana; menjelaskan frekuensi disetiap tipe kesalahan; menjelaskan kesalahanyang mendominasi; danmengidentifikasisumberkesalahan. Jenis penelitian ini adalah penelitian deskriptif kualitatif. Teknik pengumpulan data mencakup teknik
\end{abstract}


elisitasi dan dokumentasi. Langkah pertama dalam pengumpulan data adalah dengan meminta siswa menulis teks deskriptif, mengumpulkan data dalam bentuk kalimat dan paragraf, mengidentifikasi susunan teks tersebut dan menandai jenis kesalahannya, serta mendata kesalahan tersebut dan menggolongkannya ke dalam klasifikasi error. Data yang sudah terkumpul dianalisis menggunakan teori klasifikasi Dulay, Burt, dan Krashen, frekuensi setiap jenis kesalahan menggunakan teori Slamet, dan teori Brown untuk sumber error. Hasil penelitian menunjukkan bahwa siswa kelas 8 SMP AL Islam Kartasura membuat 291 kesalahan dalam penyusunan teks deskriptifyang dapat dikategorikan kedalam 3 jenis kesalahan berdasarkan kombinasi linguistic category dan surface strategy taxonomy. Tiga jenis tersebut adalah leksikal yang meliputi kesalahan ejaan 12,37\% dan kesalahan dalam penerjemahan (penggunaan bahasa Indonesia) 6,87\%. Kesalahan sintaksis meliputi penghilangan $\{-s\}$ sebagai bentuk jamak 4,12\%, penghilangan $\{-s\}$ sebagai orang ketiga tunggal 10,31\%, kesalahan pemilihan have dan has $8,25 \%$, penggunaan kata kerja-ing dalam frasa $1,72 \%$, penghilangan kata kerja 2,40\%, penghilangan to be $1,5 \%$, penambahan to be $2,40 \%$, penggunaan preposition 3,34\%, penghilangan artikel 1,37\%, penambahan artikel 1,72\%, kesalahan penempatan dalam frasa kata benda 19,93\%, kesalahan penempatan frasa 1,37\%, dan penambahan kata yang tidak perlu 5,50\%. Kesalahan wacana yang meliputi kesalahan reference 2,06\%. Penulis juga menemukan 2 sumber kesalahan yang dominan yaitu interlingual transfer dan intralingual transfer.

Kata Kunci: analisis kesalahan, teks deskriptif, linguistic category, surface strategy taxonomy.

\section{INTRODUCTION}

English is an international language. It is used all over the world. For that reason, people have to master English orally and in writing so they can communicate and socialize in the world community. In learning English, there are four skills that should be learned, namely listening, speaking, reading and writing. Listening and reading belong to receptive skills in which the language users should be able to receive spoken and written language, while speaking and writing belong to productive skills in which the language users should have the ability to produce language both spoken and written (Harmer, 1983:44).

English is the first foreign language and taught at every school in Indonesia. Every student should master English to pass the final examination. But in learning English, students often face many problems because there are many differences between English (Second Language) and Indonesia (First Language) especially in grammar.

In Indonesia, when learners applied their first language structure to the second language, they face disturbance because of the differences between their mother tongue with native language. English for Indonesian learners is a new language so that students need more time to learn and to master English. Therefore, students have to be able to create a good sentence. They have to know the basic rules to make a good sentence in English and its structure because the key to get it is grammar. Guth (1988) stated that grammar is the system which the words are combined to convey ideas and information. In addition, the study of grammar can help a writer make appropriate and mature use of the resources of the language.

For Indonesian learners, learning English is still difficult, especially because of the grammatical rules. Lado (1989:17) in Littlewood stated "besides Indonesian and English are 
different language, there are so many different elements found in them causes difficulties for Indonesian students. These elements that are similar to his native language will be simple for him and those elements that are different will be difficult."

As we know that grammar is an important thing to build writing skill in English. The students not only face difficulties in grammar, but also still get problems and difficulties in lexical and discourse. It is like teaching English in SMP AL Islam Kartasura. One of the skills to be taught is writing. The teacher gives examples of the kinds of genre text, there are recount text, descriptive text and anecdote, and also announcement, personal letter, invitation and so forth. The teacher has purposes to make student understand the material so that they can improve their skill in writing especially in constructing sentences. But, the students still make errors in constructing sentences. They still get difficulties to build a good sentence or to answer the question especially about grammar. They do it because they still use Indonesian structure to make English sentences. For example:

1. Her is beautiful girl.

2. He is have four nurses.

3. Her hair is strit.

4. Dinda is a classmate friendly..

5. I am cry.

In the first sentence of the examples above the student uses her as subjective pronoun, whereas her should belong to possessive pronoun. The second example is also false grammatically. Students use double predicates, is and have. A sentence only contain one predicate/ verb/ to be. In the third sentence, student writes strit as lurus, whereas it should be written straight. In the fourth sentence, student uses Bahasa Indonesia structure to make an English sentence. In the last sentence, the student uses double verbs in the sentence. He/she thinks that the word cry is not verb, so he/she adds to be before the word cry.

The correct sentences are:

1. She is beautiful girl.

2. He has four nurses.

3. Her hair is straight.

4. Dinda is a friendly classmate.

5. I cry.

From the phenomenon above, error analysis is a technique to anticipate the error appearing in learning English process. Dulay (1982: 141) stated that "error analysis can be characterized as an attempt to account for learner's error". Error analysis can be used to a the student in facing English examination to reduce the uncommon error.

The writer takes several references related to the study such as Lestiani (2014), the topic is "An Error Analysis of Using Simple Present Tense in Descriptive Text of the Tenth Grade Students of SMA 1 Gebog Kudus in Academic Year 2013/2014." The result of this research shows that the precentage of error types of using simple present tense in writing descriptive made by the students was $29,17 \%$ or 84 sentences. It includes the omission frequency 19 sentences $(22,62 \%)$, the addition frequency 7 sentences $(8,33 \%)$, the misformation 48 sentences $(57,14 \%)$, the misordering 10 sentences $(11,91 \%)$. All the errors above are generally caused by the lack of students' ability in using appropriate English sentence patterns. The students can make the sentences but they do not know the correct pattern.

The second research related to the writer's study done by Azizah (2014), with her topic "Errors in Recount Text Made by Tenth Grade Students of SMA Muhammadiyah 2 Surakarta." 
The result of the study showed that the tenth grade students of SMA Muhammadiyah 2 Surakarta make 176 errors in their written composition. Morphological errors consist of bound morpheme (-s) as the omission of (-s) in the plural form 4,54\%; misspelling 10,22\%; code switching 5,68\%; and false friend 2,27\%. Syntactical errors consist of omission of be 7,38\%; misuse of be $9,09 \%$; omission of it for subjective pronoun $3,40 \%$; the use of objective pronoun for subjective pronoun $4,54 \%$; omission of subjective pronoun $1,70 \%$; misuse of preposition $3,40 \%$; addition of preposition (to, on) 3,40\%; omission of (-ed) as regular verb $15,34 \%$; irregular verb 11,36\%; missordering in noun phrase 8,52\% and double marking 6,25\%. Discourse level consists of anaphoric reference $0,56 \%$; conjunction $2,27 \%$. The dominant errors are omission of (-ed) as regular verb. There are 27 errors of $15,34 \%$ from total errors. The sources of errors are interlingual transfer and intralingual transfer including ignorance of rules restriction ond over generalization.

The result of the study showed that the tenth grade students of SMA Muhammadiyah 2 Surakarta make 176 errors in their written composition. Morphological errors consists of bound morpheme (-s) as the omission of (-s) in the plural form 4,54\%; misspelling 10,22\%; code switching 5,68\%; and false friend 2,27\%. Syntactical errors consists of omission of be $7,38 \%$; misuse of be $9,09 \%$; omission of it for subjective pronoun $3,40 \%$; the use of objective pronoun for subjective pronoun $4,54 \%$; omission of subjective pronoun $1,70 \%$; misuse of preposition 3,40\%; addition of preposition (to, on) 3,40\%; omission of (-ed) as regular verb $15,34 \%$; irregular verb $11,36 \%$; missordering in noun phrase $8,52 \%$ and double marking $6,25 \%$. Discourse level consists of anaphoric reference $0,56 \%$; conjunction $2,27 \%$. The dominant errors is omission of (-ed) as regular verb. There are 27 errors of 15,34\% from total errors. The sources of errors are interlingual transfer and intralingual transfer including ignorance of rules restriction ond over generalization.

The third research was done by Mansur (2008) with her topic "An Error Analysis in Recount Writing on the Use of Simple Past Tense By the Tenth Year Students at SMK PGRI 2 Tuban." The result of the study shows that: (1) the errors in recount writing made by the tenth year students of SMK PGRI 2 Tuban are 57 occurences of all errors. The types of that errors were misformation 27 times, errors of addition 18 times, errors of omission 6 times and errors of misorder 6 times, (2) the causes of errors are over-generalization, ignorance of rules restrictions, and false concepts hyphothesized, (3) the students's problems in recount writing are structure problem $(88,9 \%)$, vocabulary problem $(77, \%)$, composing sentences $(95,6 \%)$, recount text comprehension $(37,7 \%)$. Psychological factors also influence the students, such as interest and motivation.

The last research related to the writer's study was done Syuhada (2014). The topic of Syuhada's work is "Learner's Errors in Writing Recount Text Made By Students of SMP N 1 Penawangan." The result of this study shows that the second grade of SMP Negeri 1 Penawangan make 405 errors in their compositions. The writer found that from 405 data, there are three classifications of error based on the combination of linguistic category and surface strategy taxonomy. There are $23,70 \%$ of lexical errors which covers: false friend $2,22 \%$, literal translation $18,02 \%$, and use wrong spelling 3,46\%. Errors on syntax are $76,3 \%$ covering: omission $12,1 \%$, misselection $0,99 \%$, tenses $51,11 \%$, misordering $11,60 \%$, sentence pattern $0,49 \%$. The highest frequency of errors that the reseacher found is the uses of V1 in state of V2 in writing recount text. There are 13,09\% (53) errors found from the total errors. The sources of errors are interlingual transfer and intralingual transfer.

Based on the explanation above, there are many differences between the writer's findings with the previous studies findings. The differences are laid on lexical, syntactical, discourse and the sources of errors. Compared with Lestiani's, the writer's finding does not involve 
misformation errors. But the writer's finding is larger than her, because she also focused on the use of simple present. The sources of Lestiani's finding is the lacking of knowledge, while the writer's sources of error is more specific, that is intralingual transfer and interlingual transfer. Compared to Azizah's, her findings is larger than the writer's because the writer's does not involve the morphological aspect. The writer's finding only focused in lexical, syntactical and discourse. Next, compared with Mansur's finding, the writer's does not involve misformation, and his source is only interlanguage transfer. While, the writer's finding of sources of error are intralingual transfer and interlingual transfer. The last, compared with Syuhada's findings, his findings is does not involve discourse error because the students make the text based on the picture that describes the seuencing event. The difference also laid on the frequency of errors. It is occured because the number of data between the writer and all the previous studies were different.

\section{RESEARCH METHOD}

This study is a qualitative one which focuses on error analysis of descriptive text which are made by eighth grade students of SMP AL Islam Kartasura. Moleong (1998:2) defined descriptive qualitative is a method of doing the research that contains descriptive data such as written or verbal words from the people and the other behavior that can be observed.

This study was conducted at SMP AL Islam Kartasura. The subject of the study is limited to on the students of class 8A that consists of 29 students and class $8 \mathrm{D}$ that consist of 24 students of SMP AL Islam Kartasura in 2015/2016 academic year. The object of this research is the error which are made by the students in writing descriptive text. The data are taken from the document of students' product. That is the form of erroneous sentences and paragraph made by students. The data sources are the composition written produced by the second grade students.

The writer uses elicitation method in her research to get the data. Elicitation method is the method to elicit students to produce language. Nunan (in Fauziati, 2002:135) adduced that elicitation techniques vary enormously in scope, aim, and purpose. They included studies, which obtain their data by means of stimulus, such as picture, diagram or standardized text, as well as those based on questionnaire, survey, and interview data.

Using this technique, the writer correct the data, present the data and draw conclusion. The data are analyzed by taking the following steps: Identification of errors, classifying into the error types, describing the frequency of errors, describing the dominant type of error, describing the sources of error.

\section{FINDING AND DISCUSSION}

The writer presents the research finding and the discussion of the learner's errors in writing descriptive text made by students of SMP AL Islam Kartasura. The research findings show types of error, frequency of error, dominant error and sources of error of students product in writing descriptive text made by eighth grade students.

The research findings were analyzed based on the research problems. In line with the research problems this research findings and discussion present some point based on data analysis, they are: type of lexical error, type of syntactical, type of discourse, frequency of error, dominant of error and sources of error.

\section{Type of Lexical Error}

The writer found many errors in lexical form made by the students (56 error or 19,24\%). 
They are misspelling and literal translation (the use of Indonesian construction).

a. Misspelling relates to vocabulary. Looking up Oxford Dictionary, spelling is the activity of writing or naming the letters of a word. James (1998: 133) stated that Misspelling is the misselection of a grapheme to represent a syllable or morpheme in forming part of a word. For example "She have tri family." The students represent a sound using a letter which is identical to the sound of that letter name. The correct word is three.

b. Literal translation (the use of Indonesian construction) is the translation of the text from one language to other language "word - for - word" rather than giving the meaning to the original. The students still use Indonesian construction when they write English text. They write English sentences by translating each word into Indonesian. For example "Hobby he football." The students used he for subject pronoun. The sentence should use possesive his for subject.

Compared with previous finding, Syuhada and Mansur. Syuhada's finding (2014) in lexical error are wrong spelling, false friend and literal translation. In Mansur finding (2008), there is no error in lexical type because he only focused on the use of past tense in writing recount text. The reseacher found that the students of SMP AL Islam made misspelling and literal translation in lexical types of error.

\section{Type of Syntactical Error}

In this study, the writer found that the students made syntactical error such as the use of $\{-\mathrm{S}\}$ as plural marker, the use of $\{-\mathrm{S}\}$ as third singular marker, predicate in sentence, preposition, article, and phrase.

\section{a. The Use Of $\{-S\}$ As Plural Marker}

In English, plurals marker of noun is indicated by $(-\mathrm{s})$ or $(-\mathrm{es})$ letter in the end of word. The $(-\mathrm{s})$ or $(-\mathrm{es})$ in the end of word is used when the subject of the sentences is plural. The writer found omission of $\{-\mathrm{S}\}$ as plural marker. Omission is indicated by the absence of an item that must appear in a correct formed utterance (Fauziati 2009 : 145). For example "My family has four member." The students omit (-S) letter as plural marker. The words should be precede by plural word, so the correct word is members.

\section{b. The Use Of $\{-S\}$ As Third Singular Marker In Present Form}

English structure has rules for building sentences or utterances. One of that rule is the use of $(-\mathrm{S})$. The $(-\mathrm{S})$ is used in the sentence when the subject pronouns are he, she and it. The students do not understand that rule by omitting (-S) as third singular marker. For example "She always play with me." This sentence should use (-S) in the predicate because the subject is third singular person and the form is present tense. The correct word is plays.

\section{c. Predicate In A Sentence}

Predicate tells what subject is or does. There are two kinds of predicate error in a sentence, namely verb and be. Verb is the important part of a sentence. In this case, the students made 3 kinds of error in verb, such as miss-selection of have instead of has, for example "She have three sibling". Here, the student is false in choosing verb. The sentence uses singular person as subject, so the correct word is has. The use of verb-ing, for example "He like eat fried rice." Here, the student built a sentence with two verbs. The correct sentences are using to eat or eating. And omission of verb, for example "She 
.....flat nose." The student omits the verb that should be present. So the correct sentence should use has. Correct sentence always contains verb in the composition. If there is no verb in a sentence, it can be given linking verb, such as BE. The writer classified the error into omission of $\mathrm{BE}$ as full verb and addition of $\mathrm{BE}$ as full verb. The students do not understand or forget to give to be in their sentence. They still confuse about to be, so they omitted to be. For example "Her name .... Lutfi." the students also do not know that not all of sentences use to be. They only know that after subject should use to be. For example "She is has long hair." That is incorrect sentence, the correct one is without to be $i s$.

\section{d. Preposition In Prepositional Phrase}

Phrase consist of head and modifier. Preposition phrase usually consist of preposition as a head and noun phrase or noun as a modifier. The students wanted to make prepositional phrase but, they omitted the head. For example "Iam really good .... playing football." The correct sentence is using in. In several case, students added preposition in their sentences. So, there are double preposition in the prepositional phrase, such as "We family go to in the park." So, the correct is without in.

\section{e. Article}

An article is a word that is combined with a noun. Article is used to indicate the type of reference which is made by the noun. There are article in English, namely the, a and an. The writer found two kinds of error, namely omission and addition of article. For example "Flowers very aromatic". The students omitted the article that should appear in the composition. The correct is by adding article the to the sentence. Example of addition "She school in the SMP". The students added article the in their sentences. They do not know the function of an article. The correct sentences is by omitting article the in the sentences.

\section{f. Phrase}

Phrase is a group of words that can stand autonomously. A phrase does not contain subject and predicate or verb. There are three errors, namely misordering in noun phrase and phrase and addition of unnecessary word. Misordering errors are characterized by incorrect placement of a morpheme of group of morphemes in an utterance (Krashen, 1982: 162). Noun phrase is a group of words that consist of head and modifier. The students make error like the example "I have friend good." The student made incorrect order, friend is a head and good is a modifier. That should be good friend. Then, the example of misordering in noun phrase "She was brown 20 Oktober 2001." The students are still confused or do not understand about English rule in writing date. It is different from Indonesian rule. The correct order is "She was born at October, 20 2001" or "She was born at October, 20th 2001." The last, is addition of unnecessary word. The student made ineffective sentence by adding unnecessary word, for example "I have friend classmate.". It can be more effective if the students ommited word friend. The reseacher compares to previous finding, Azizah (2014). Azizah's finding in syntactical error are omission of $b e$, misuse of be, omission of it for subjective pronoun, the use of objective pronoun for subjective pronoun, omission of subjective pronoun, misuse of preposition, addition of preposition (to, on), omission of (-ed) as regular verb, irregular verb, missordering in noun phrase, and double marking. It can be concluded that in writing descriptive text, the students of SMP AL Islam made many mistake in omission, addition, misordering, and misselection. 


\section{Type of Discourse Error}

The discourse error is related to the way for organizing and linking the sentences in order to build a whole text. There is only one error, namely reference. Reference is one of discourse components. Reference is the use of pronouns, comparative, demonstrative and definite article to indicate the semantic identify of an item with the other. Like the example "Finally, my sister, Heni. He is 21 years old." The students made errors in the use of possesssive adjective pronoun. The students thought that his refers to she, he refers to my sister. The correct sentence is Finally, my sister, Heni. She is 21 years old.

The writer compares with Syuhada finding (2014), there is no discourse error on the students product in writing recount text because the students made the story appropriate with the picture.

\section{The Frequency of Error}

The writer found 291 errors made by students. Those are arranged into table below:

Table 1. Type of errors

\begin{tabular}{|c|c|c|c|}
\hline No. & Type of Errors & $\begin{array}{c}\text { Number of } \\
\text { Error }\end{array}$ & $\begin{array}{c}\text { Frequency of } \\
\text { Error }\end{array}$ \\
\hline \multirow[t]{3}{*}{$\mathbf{I}$} & The Types of Lexical Error & 56 & $19,24 \%$ \\
\hline & a. Misspelling & 36 & $12,37 \%$ \\
\hline & b. The use of Indonesian Construction & 20 & $6,87 \%$ \\
\hline \multirow[t]{13}{*}{ II } & The Types of Syntactical Error & 229 & $78,48 \%$ \\
\hline & a. Misordering in noun phrase & 58 & $19,93 \%$ \\
\hline & b. Omission of be & 47 & $16,15 \%$ \\
\hline & c. Omission of $\{-\mathrm{S}\}$ as third singular person & 30 & $10,31 \%$ \\
\hline & d. Misselection of have instead of has & 24 & $8,25 \%$ \\
\hline & e. Addition of unnecessary word & 16 & $5,50 \%$ \\
\hline & f. The use of Preposition & 10 & $3,44 \%$ \\
\hline & g. Omission of verb & 7 & $2,40 \%$ \\
\hline & h. Addition of be & 7 & $2,40 \%$ \\
\hline & i. Addition of article & 5 & $1,72 \%$ \\
\hline & j. The use of verb-ing & 5 & $1.72 \%$ \\
\hline & k. Omission of article & 4 & $1,37 \%$ \\
\hline & 1. Misordering in phrase & 4 & $1,37 \%$ \\
\hline \multirow[t]{3}{*}{ III } & The Type of Discourse Error & 6 & $2,06 \%$ \\
\hline & Reference & 6 & $2,06 \%$ \\
\hline & Total & 291 & $99,78 \%=100 \%$ \\
\hline
\end{tabular}

\section{The Dominant Type of Error}

The dominant type of error is syntactical error especially syntactical error in misordering in noun phrase with total number of 58 errors or $19,93 \%$ of errors because it has highest frequency.

It is found that there are some different findings. Compared to the previous finding, Lestiani (2014) and Mansur (2008), there are some differences. Lestiani findings showed that the dominant error is on the misformation sentences with 48 errors or 57,14\%. And Mansur finding showed the dominant error is on composing sentences $(95,6 \%)$. 


\section{The Sources of Error}

The writer found interlingual error and intralingual error within students' errors. This means that interlingual transfer and intralingual transfer are badly influential to the students' writing. It can be concluded that the most errors frequently made by the students is on syntactical error.

The reseacher compares with the previous finding, Syuhada (2014) and Azizah (2014). There is similar sources between the current finding and the previous finding. There are intralingual transfer and interlingual transfer.

\section{CONCLUSION}

The result of the analysis is that the fifty three student's compositional works produced 291 errors which are classified into three main categories, namely: lexical errors (56 errors or $19,24 \%$ ), syntactical errors (229 errors or $78,48 \%$ ) and discourse errors (6 errorr 2,06\%). The most errors made by the students are syntactical errors, especially on misordering in noun phrase that consists of 58 errors equaling 19,93\%. The sources of students error found by the writer are 'Intralingual Transfer' and 'Interlingual Transfer'.

\section{REFERENCES}

Azizah, Dewita Nur. 2014. Errors in Recount Text Made by Tenth Grade Students of SMA Muhammadiyah 2 Surakarta. Skripsi: UMS.

Dulay, Burt, and Krashen. 1982. Language Two. New York: Oxford University Press.

Dulay, Heidi. 1982. Language Two. New York: Oxford University Press.

Fauziati, Endang. 2009. Reading on Applied Linguistics. Surakarta: Muhammadiyah University Press.

Harmer, J. 1983. The Practice of English Language Teaching. London: Longman.

James, Carl. 1998. Errors in Language Learning and Use: Exploring Error Analysis. London: Routledge.

Lestiani, Siti Ari. 2014. An Error Analysis of Using Simple Present Tense in Descriptive Text of the Tenth Grade Students of SMA 1 Gebog Kudus in Academic Year 2013/ 2014. Skripsi: Muria Kudus University.

Mansur. 2008. An Error Analysis in Recount Writing on the Use of Simple Past Tense By the Tenth Year Students at SMK PGRI 2 Tuban. Skripsi. University of PGRI Ronggolawe.

Moleong. 1989. The Kind of Research. http://www.research.org. Accessed at 10.00 pm, January $15,2016$.

Syuhada, Shonnifaul. Learner Errors in Writing Recount Text Made By Students of SMP N 1 Penawangan. Skripsi. UMS 